\title{
ASPEK LEKSIKAL DAN GRAMATIKAL PADA LIRIK LAGU JIKA KARYA MELLY GOESLOW
}

\author{
Rini Agustina \\ Program Studi Pendidikan Bahasa dan Sastra Indonesia \\ IKIP PGRI Pontianak \\ brentex32@yahoo.co.id
}

\begin{abstract}
This study focuses on lyrics If the work Meely Goeslow. The approach used is a micro-structural approach focuses on the aspects of lexical and grammatical aspects. The results showed that grammatical elements contained in the lyrics of the song if it was that the reference ( reference), deletion (Ellipsis), and the coupling (conjungtion). Lexical items contained in the song If are reps ( repetitions ), synonymy ( equivalent words), and the antonym (opposite).

Keywords : lexical, grammatical, songs
\end{abstract}

\begin{abstract}
ABSTRAK
Penelitian ini berfokus pada lirik lagu Jika karya Melly Goeslow. Pendekatan yang digunakan adalah pendekatan mikrostruktural yang menitikberatkan pada aspek leksikal dan aspek gramatikal. Hasil penelitian menunjukkan bahwa unsur gramatikal yang terkandung di dalam lirik lagu jika adalah pengacuan (referensi), pelesapan (Ellipsis), dan perangkaian (conjungtion). Unsur leksikal yang terdapat dalam lagu Jika adalahrepetisi (pengulangan), sinonimi (padan kata), dan antonimi (lawan kata).
\end{abstract}

Kata kunci: leksikal, gramatikal, lagu

\section{PENDAHULUAN}

Manusia merupakan makhluk

sosial yang tidak bisa hidup sendiri oleh

karena itu untuk berinteraksi dengan

makhluk yang lain memerlukan suatu alat

yang disebut dengan bahasa. Seperti yang

diungkapkan oleh Gorys Keraf (1997 : 1)

yang mengatakan bahasa adalah alat

komunikasi antara anggota masyarakat berupa simbol bunyi yang dihasilkan oleh alat ucap manusia. Bahasa merupakan suatu sistem komunikasi yang mempergunakan simbol-simbol vokal (bunyi ujaran) yang bersifat arbitrer, yang dapat diperkuat dengan gerak-gerik badaniah yang nyata. Ia merupakan simbol karena rangkaian bunyi yang dihasilkan oleh alat ucap manusia harus diberikan 
makna tertentu pula. Simbol adalah tanda yang diberikan makna tertentu, yaitu mengacu kepada sesuatu yang dapat diserap oleh panca indra. Berarti bahasa mencakup dua bidang, yaitu vokal yang dihasilkan oleh alat ucap manusia, dan arti atau makna yaitu hubungan antara rangkaian bunyi vokal dengan barang atau hal yang diwakilinya, itu. Arti yang terkandung dalam suatu rangkaian bunyi bersifat arbitrer atau manasuka.

Menurut Felicia (2001 : 1) dalam berkomunikasi sehari-hari, salah satu alat yang paling sering digunakan adalah bahasa, baik bahasa lisan maupun bahasa tulis. Bahasa sebagai sarana komunikasi mempunyai fungsi utama sebagai penyampaian pesan atau makna oleh seseorang kepada orang lain. masyarakat. Melalui bahasa kita dapat menyatakan secara terbuka segala sesuatu yang tersirat di dalam dada dan pikiran kita. Misalnya seperti seorang penulis buku, mereka akan menuangkan segala seseuatu yang mereka pikirkan ke dalam sebuah tulisan tanpa memikirkan si pembaca, mereka hanya berfokus pada keinginan mereka sendiri.

Seorang penulis dapat menungkan pikirannya melalui berbagai media satu diantaranya melalui lirik lagu. Banyak penulis lagu membuat karya-karya mereka berdasarkan perasaan yang sedang mereka alami. Selain berdasarkan pengalaman pribadi ada juga yang berdasarkan lingkungan sekitar mereka, seperti kisah hidup keluarga, saudara, dan teman.

Seni tidak bisa terlepas dari kehidupan manusia, sebab seni tumbuh dan berkembang ditengah-tengah kehidupan manusia. Pada dasarnya seni bersumber dari perasaan manusia seperti sedih, senang, marah, kecewa, cinta atau perasaan lainnya yang berhubungan dengan naluri kita masing-masing sebagai manusia.

Semua perasaan itu dapat diungkapkan oleh pencipta atau pelaku seni melalui media bunyi, atau suara, gerak, rupa, kata-kata, tingkah laku secara tepat sehingga dapat diterima dan dirasakan oleh pencipta dan pengamat seni. 
Seni merupakan bagian dari musik atau bisa dikatakan bahwa musik adalah cabang seni, mengapa dikatakan seperti hal diatas karena musik dan seni memiliki hubungan yang erat bahkan erat dengan sejarah peradaban manusia.

Menurut Kosashi (1994:418) menyatakan bahwa:

"Musik merupakan tempat dimana manusia mencurahkan perasaan hati, tempat melukiskan getaran jiwa khayal yang timbul dalam pikiran yang mana tidak dapat dicetuskan dengan perantaran katakata, perbuatan atau dengan perantaraan suatu bidang seni lain

Lagu yang akan dianalisis dalam tulisan ini adalah lagu jika yang dinyanyikan Melly Goeslow dan Ari Laso, dan diciptaan oleh Melly Goeslow. Lagu ini akan di analisis dari aspek kohesi leksikal dan gramatikalnya. Kohesi merupakan aspek-aspek yang membentuk sebuah wacana sehingga wacana tersebut menjadi utuh. Menurut Halliday (dalam Oktafianus, 2006:53) kohesi merupakan hubungan semantis yang ada dalam suatu teks.

Menurut Oktafianus (2006:53), kohesi akan muncul apabila interpretasi suatu unsur tergantung pada unsur lain dalam suatu teks atau wacana. Kohesi dibagi menjadi dua bagian, yaitu kohesi gramatikal dan kohesi leksikal. Kohesi gramatikal terdiri dari referensi, substitusi, elipsis, konjungsi, sedangkan kohesi leksikal terdiri dari repetisi, sinonim, antonim, hiponim, dan kolokasi. Menurut Halliday dan Hasan (dalam Trigan, 1987:97-103), pembagian kohesi tersebut dibagi menajadi lima aspek sarana kohesi yaitu pronomina, substitusi, elipsis, konjungsi, dan kohesi leksikal.

\section{METODE PENELITIAN}

Penelitian ini menggunakan pendekatan mikrostruktural yang berupa kohesi leksikal dan kohesi gramatikal. Bentuk penelitian ini adalah deskripsi kualitatif. Sumber data penelitian ini yaitu lirik lagu Jika karya Melly Goeslow. 
Teknik pengumpulan. Data dalam kajian ini dianalisis dengan menggunakan teknik catat.

\section{PEMBAHASAN}

\section{Analisis Aspek Gramatikal}

Aspek gramatikal wacana dalam analisis lagu "Jika" ini meliputi pengacuan (reference), penyulihan (subtitution), pelesapan (ellipsis), dan perangkaian (conjungtion).

\section{a. Pengacuan (referensi)}

Sumarlam (2008: 29) mengatakan referensi atau pengacuan adalah salah satu jenis kohesi gramatikal yang berupa satuan lingual tertentu yang menunjuk satuan lingual yang mendahului atau mengikutinya.Referensi adalah hubungan antara simbol dengan benda yang diacu (Ogden dan Richards dalam Oktafianus, 2006:53). Dalam aspek gramatikal terdapat tiga jenis pengacuan, yakni pengacuan persona, demonstratif, dan komparatif. Dalam analisis lirik lagu "Jika" ini, hanya terdapat satu jenis pengacuan, yakni pengacuan persona.

Pada lirik lagu "Jika" terdapat dua jenis pengacuan persona, yakni pronomina pertama tunggal dan pronominal kedua tunggal. Pengacuan persona pronominal pertama tunggal terdapat dalam kutipan lirik sebagai berikut.

1) Apakah sama yang kurasa $\{8\}$

2) Kan kudengar caci dan puji dirimu padaku. $\{13\}$

3) Maafkan daku ingin kembali.

Penggunaan kata $k u$ pada kutipan (1) dan (2), adalah pronominal persona pertama tunggal bentuk terikat. Kata ku dalam lirik tersebut juga merupakan pengacuan endofora karena yang diacu dalam lirik tersebut berada di dalam teks, yaitu mengacu pada orang yang sedang bernyanyi. Kata daku pada kutipan (3) merupakan pronominal persona pertama tunggal bentuk bebas. Kata daku juga merupakan pengacuan 
endofora, karena yang diacu dalam kata tersebut berada di dalam tekas, yaitu orang yang sedang bernyanyi.

Sedangkan pengacuan persona pronominal kedua tunggal dalam lagu ini terdapat di dalam kutupan lirik berikut ini.

4) Jika teringat tentang $\operatorname{dikau}\{1\},\{6\}$, $\{17\},\{20\}$.

5) Kan kudengar caci dan puji dirimu padaku. $\{13\}$

Penggunaan kata dikau dan dirimu pada kutipan (4) dan (5) adalah pronominal persona kedua tunggal bentuk bebas. Kata dikau dan dirimu dalam lirik tersebut juga merupakan pengacuan endofora karena yang diacu dalam lirik tersebut berada di dalam teks, yaitu mengacu pada lawan bernyanyinya.

6) Tak ada niat untuk berpisah denganmu $\{10\}$ dan $\{22\}$

Penggunaan kata -mu pada kutipan (6) adalah pronominal kedua tunggal bentuk terikat. Kata -mu pada kutipan tersebut juga merupakan pengacuan endofora karena yang diacu dalam lirik tersebut berada di dalam teks, yaitu mengacu pada lawan bernyanyinya.

\section{b. Pelesapan (Ellipsis)}

Elipsis merupakan peniadaan kata atau satuan lain yang wujud asalnya dapat diramalkan dari konteks bahasa atau konteks luar bahasa (Kridalaksana, 1984: 45). Menurut Sumarlam (2008: 38) Elipsis merupakan salah satu jenis kohesi gramatikal yang berupa penghilangan unsur (konstituen) tertentu yang telah disebutkan sebelumnya. Pelesapan atau penghilangan satuan lingual tertentu sering digunakan para pencipta lagu untuk tujuan estetika. Lagu "Jika" juga memuat lirik-lirik yang mengalami pelesapan. Pelesapan dalam lagu tersebut dapat ditemukan pada kutipankutipan berikut.

7) Sempat terfikir \#tuk kembali \{3\}

- Sempat terfikir untuk kembali 
8) Walau \#beda akan \#ku jalani $\{4\}$

- Walau berbeda akan aku jalani

9) T\#\#ak ada niat untuk selamanya pergi $\{5\}$ dan $\{19\}$

\section{c. Perangkaian (conjungtion)}

- Tidak ada niat untuk selamanya pergi.

Menurut Sumarlam (2008: 40) Konjungsi merupakan salah satu kohesi gramatikal yang dilakukan dengan cara

10) Apakah sama yang \#ku rasa\# $\{8\}$

- Apakah sama yang aku rasakan.

11) Ingin \#jumpa walau ada \# segan

- Ingin berjumpa walau ada rasa segan.

12) T\#\#ak ada niat untuk berpisah denganmu $\{10\}$ dan $\{22\}$ menghubungkan unsur yang satu dengan unsur yang lain dalam wacana. Konjungsi adalah yang dipergunakan untuk menggabungkan kata dengan kata, frase dengan frase, klausa dengan klausa, kalimat dengan kalimat, serta paragraf dengan paragraf (Kridalaksana, 1984: 105).Bentuk

- Tidak ada niat untuk berpisah denganmu.

13) Jika memang masih bisa mulutku \# berbicara $\{11\},\{23\},\{29\}$, dan $\{30\}$.

- Jika memang masih bisa mulutku untuk berbicara.

14) \#kan \#ku dengar\# caci\# dan puji\# dirimu padaku $\{13\},\{25\},\{31\}$, dan

- Akan aku dengarkan cacian dan makian dirimu padaku. perangkaian terdapat dalam lirik lagu "Jika". Terdapat lima bentuk perangkaian atau konjungsi, yaitu konjungsi walau yang menunjukkan perangkaian kosesif, konjungsi untuk yang menunjukkan perangkaian tujuan, konjungsi dan yang menggambarkan perangkaian menghubungkan kata dengan kata, konjungsi yang, yang menunjukan perangkaian atributif dan jika yang menggambarkan perangkaian 
syarat. Lima bentuk konjungsi tersebut dapat dilihat pada kutipan berikut.

15) Walau beda akan kujalani

16) Ingin jumpa walau ada segan

17) Sempat terfikit $t u k$ kembali

18) Tak ada niat untuk berpisah denganmu

19) Tak ada niat untuk selamanya pergi

20) Kan kudengar caci dan puji ditimu padaku

21) Jika teringat tentang dikau $\{1\},\{6\},\{17\},\{20\}$.

22) Jika memang masih bisa mulutku berbicara $\{11\},\{32\}$, $\{29\}, \operatorname{dan}\{35\}$

23) Apakah sama yang kurasa

24) Satu kata yang ingin terucap

\section{Analisis Aspek Leksikal}

Aspek leksikal wacana menitikberatkan pada segi makna atau struktur batin sebuah wacana. Aspek leksikal wacana dalam lirik lagu "Jika" meliputi repetisi (pengulangan), sinonimi (padan kata), kolokasi (sanding kata), hiponimi (hubungan atas bawah), dan antonimi (lawan kata).

\section{a. Repetisi (Pengulangan)}

Menurut Oktafianus (2006:63), repetisi merupakan pemunculan bentuk yang sama yang mengacu ke makna yang sama dalam suatu wacana. Sedangkan menurut Sumarlam $(2008 ; 43)$ repetisi adalah pengulangan satuan lingual (bunyi, suku kata, kata, maupun bagian kalimat) yang dianggap penting untuk memberi tekanan dalam sebuah konteks yang sesuai.Wacana berupa lagu sering ditemukan bentuk repetisi di dalamnya, terutama repetisi bait atau refren. Pada lagu "Jika" ditemukan repetisi bait yakni pada larik \{1dan2\} yang diulang pada lagi pada larik $\{6$ dan7 $\},\{17$ dan 18$\}$ dan $\{20$ dan 21 \}. Selain itu repetisi bait juga terdapat pada larik $\{5$ dan 10$\}$ yang mengalami repetisi pada larik \{14 dan 22\}. Bait tersebut dapat dilihat sebagai berikut. 
25) Jika memang masih bisa mulutku berbicara

26) jika memang masih bisa mulutku berbicara

27) Satu kata yang ingin terucap

28) Kan kudengar caci dan puji dirimu padaku

29) Kita masih muda dalam mencari keputusan

30) Maafkan daku ingin kembal

31) Seumpama ada jalan untuk kembali

Pengulangan refren dalam lagu ini terjadi empat kali pengulangan yaitu pada bait $\{23-40\}$. Selain itu juga terdapat pengulangan pada lirik,

32) Kita masih muda dalam mencari keputusan

33) Maafkan aku ingin kembali

34) Seumpama ada jalan untuk kembali

Pada lirik di atas terjadi pengulangan lagi pada lirik $\{41-43\}$. Pengulangan larik juga ditemukan dalam lirik lagu "Jika". Pengulangan larik dapat dicontohkan sebagai berikut

35) Tak ada niat untuk selamanya pergi $\{5\}$

Larik di atas berada pada baris \{5\} dalam lagu tersebut, kemudian mengalami repetisi pada baris $\{19\}$.

36) Tak ada niat untuk berpisah denganmu $\{10\}$

Larik di atas berada pada baris $\{10\}$ kemudian mengalami repetisi pada baris $\{22\}$.

Pengulangan kata pada lagu "Jika" dapat dijabarkan sebagai berikut

37) Jika teringat tentang dikau $\{1\},\{6\},\{17\},\{20\}$.

38) Jika memang masih bisa mulutku berbicara $\{11\}$

Berdasarkan data di atas, maka dapat dilihat bahwa kata jika mengalami lima kali pengulangan.

\section{b. Sinonimi (Padan Kata)}

Sinonimi atau padan kata merupakan alat kohesi leksikal dalam 
wacana yang menunjukkan pemakaian

lebih dari satu bentuk bahasa yang secara semantik memiliki kesamaan atau kemiripan (Sumarlam, 2008:47).Sinonim merupakan persamaan arti tetapi memiliki bentuknya berbeda. Kekayaan budaya dan intensitas kontak dengan bahasa lainnya menentukan warna persinoniman dalam suatu bahasa (Oktafianus, 2006:64). Sinonimi merupakan salah satu aspek leksikal yang mendukung kepaduan wacana. Sinonimi berfungsi sebagai penjalin hubungan makna yang sepadan antara satuan lingual tertentu dengan satuan lingual lain dalam wacana.

Lagu "Jika" memuat dua sinonimi, yakni sinonimi morfem dan sinonimi kata.

39) Jika teringat tentang dikau $\{1\},\{6\}$, $\{17\},\{20\}$.

40) Kan kudengar caci dan puji dirimu padaku
Pada teks di atas, morfem bebas dikau bersinonim dengan morfem terikat $-m u$

41) Kan kudengar caci dan puji dirimu padaku

42) Maafkan daku ingin kembali

Pada teks di atas, morfem terikat $k u$ bersinonim dengan morfem bebas daku

\section{c. Antonimi (Lawan Kata)}

Antonim adalah lawan kata. Suatu wacana yang dinamis juga sering menempatkan kohesi leksikal secara fleksibel dan variatif dengan mempertentangkan makna yang berlawanan (Oktafianus, 2006:64). Antonimi atau lawan kata disebut juga dengan oposisi makna. Oposisi makna merupakan konsep yang betul-betul berlawanan sampai kepada yang hanya kontras makna saja.Berdasarkan sifatnya, oposisi makna dapat dibedakan menjadi lima macam, yaitu oposisi mutlak, oposisi kutub, oposisi hubungan, oposisi hirarkial, dan oposisi majemuk. 
Dalam lagu "Jika" terdapat

beberapa antonim, adapun antonim

tersebut akan dipaparkan sebagai

berikut.

43) Jauh di mata dekat dihati

Pada lirik di atas morfem bebas jauh berantonim dengan morfem bebas dekat.

44) Jika teringat tentang dikau

45) Maafkan daku ingin kembali

Pada lirik di atas, morfem bebas dikau, berantonim dengan morfem bebas daku

46) Sempat terfikir tuk kembali

47) Tak ada niat untuk selamanya pergi

Berdasarkan contoh lirik di atas maka morfem bebas kembali, berantonim dengan morfem bebas pergi

48) Kan kudengar caci dan puji dirimu padaku

Pada lirik di atas menunjukkan bahwa morfen caci berantonim dengan morfem puji.

\section{PENUTUP}

Lagu "Jika" ciptaan Melly Goeslow ini merupakan lagu yang mempunyai unsur gramatikal dan unsur leksikal. Adapun unsur gramatikal yang terkandung di dalamnya adalah pengacuan (referensi), pelesapan (Ellipsis), dan perangkaian (conjungtion). Unsur leksikal yang terdapat dalam lagu "Jika" adalahrepetisi (pengulangan), sinonimi (padan kata), dan antonimi (lawan kata)

\section{DAFTAR PUSTAKA}

Dewa, I Putu Wijana dan M.Rohmadi. 2009. Analisis Wacana Pragmatik: Kajian Teori dan Analisis. Surakarta: Yuma Pustaka.

Keraf, Gorys. 2004. Diksi dan Gaya Bahasa. Jakarta: Gramedia Pustaka Utama.

Kosasih, H.E. 2003. Ketatabahasaan dan Kesusastraan. Bandung: CV. Yrama Widya

Mulyana. 2005. Kajian Wacana Teori, Metode, \& Aplikasi Prinsip-Prinsip Analisis Wacana. Yogyakarta: Tiara Wacana.

Oktafianus. 2006. Analisis Wacana Lintas Bahasa. Padang: Andalas University Press.

Sumarlam. Ed. 2008. Teori dan Praktik Analisis Wacana. Surakarta: Pustaka Cakra.

Tarigan, H. G. 1987. Pengajaran Wacana. Bandung: Penerbit Angkasa. 